\title{
Contribution of Agricultural Sector and Sub Sectors on Indonesian Economy
}

\author{
Refa'ul Khairiyakh*, Irham, Jangkung Handoyo Mulyo \\ Social Economy of Agriculture, Faculty of Agriculture, Universitas Gadjah Mada, Yogyakarta \\ *email: rvieriya@yahoo.com
}

\begin{abstract}
This research aimed to analyze trend of agricultural GDP and agricultural contribution in Indonesia, and identify the role of agricultural sector and sub sectors in provinces of Indonesia. Source of data this research use linear trend analysis to analyze trend agricultural Gross Domestic Product (GDP) and agricultural contribution. Location Quotient (LQ), Dynamic Location Quotient (DLQ), and combination LQ and DLQ is used to identify the role of agricultural sector and sub sectors. The analysis found that agricultural GDP in Indonesia has increasing trend while agricultural contribution has decreasing trend. Agricultural sector is basic sector in 29 provinces in Indonesia. Farm food crop is leading sub sector in 6 provinces, farm non food crops is leading sub sector in 14 provinces, livestock is leading sub sector in 3 provinces, forestry is leading sub sector in 1 provinces, fishery is leading sub sector in 5 provinces.
\end{abstract}

Keywords: Agricultural Sector, Linear Trend, LQ and DLQ

\section{INTRODUCTION}

Agricultural sector has a vital role in national economy through its of Gross Domestic Product (GDP), foreign exchange, provision of food and raw materials, poverty alleviation; provide employment where agricultural sector can absorb more than $35 \%$ of total workforce, and the increase in people's income. Beside its direct contributions, the agricultural sector also has indirect contribution of multiplier effect which is the input-output linkages between industries, consumption and investment. The multiplier impact is relatively large so that the agricultural sector as the main sector deserves national economic development (Anonim, 2006).

Agricultural development in Indonesia will be faster if it is supported by development planning in the regional and national. One of determinant factors on agricultural development among others policy and programs. Appropriate policies and programs of agricultural development is a principal source of agricultural progress in order to make agricultural development can be done well

Since appropriate policy and program is critical, the government should be careful to take decisions about policies and programs of agricultural development. For this purpose, Indonesian government needs information about the condition of the agricultural sector both nationally and regionally. By this way, it is expected that implementation of policies and programs of agricultural development will be more effective and efficient. This research aimed to analyze trend of agricultural GDP trend of agricultural contribution on GDP in Indonesia during the last 20 years, and identify the role of agricultural sector and sub sector in each provinces of Indonesia.

\section{MATERIALS AND METHODS}

Trend of agricultural GDP and agricultural contribution on GDP during the last 20 years is analyzed by linear trend with the equation as follows:

Where:

$$
\mathrm{Y}=\beta_{0}+\beta_{1} \mathrm{~T}+
$$

$\mathrm{Y}=$ Agricultural GDP or Agricultural

Contribution

$\beta_{0}=$ Constant

$\beta_{1}=$ Coefficient of regression

$\mathrm{T}=$ Period of study (1993-2012)

$\mu \quad=$ Error

Location Quotient (LQ) is used to know the role of economic sector/sub sector, wether they are basic or non basic sector. LQ analysis to agricultural sector in each province of Indonesia can be done by the formula follow (Tarigan, 2009): 
Where:

$$
\mathrm{LQ}=\frac{x_{i} / e_{i}}{x_{i} / E_{i}}
$$

$\mathrm{xi}=$ value added of agricultural sector or sub sectors in region

ei $=$ Regional Gross Domestic Product

$\mathrm{Xi}=$ value added of agricultural sector/sub sectors in national

Ei $=$ Gross Domestic Product

The criteria:

$\mathrm{LQ}>1$, it means that agricultural sector is basic sector.

$\mathrm{LQ} \leq 1$, it means that agricultural sector is non basic sector.

Determinate of agricultural basic sub sectors in the region after not only use LQ analysis but also use DLQ analysis and combination both of them to identify of agricultural classification. Dynamic Location Quotient (DLQ) is the modification of LQ. DLQ accommodate the growth rate from time to time (Kuncoro, 2012). DLQ of agricultural sector can be formulated as:

$$
\mathrm{DLQ}=\left[\frac{\left(1+\mathrm{g}_{i j}\right) /\left(1+\mathrm{B}_{i}\right)}{\left(1+\mathrm{G}_{i}\right) /(1+\mathrm{G})}\right]^{\mathrm{t}}
$$

Where:

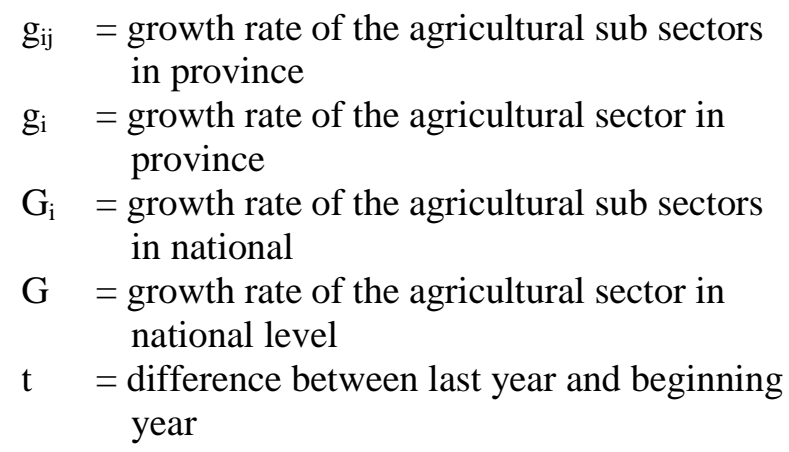

The criteria:

DLQ $>1$, it means agricultural sub sector is expectable to be basic sector in the future.

DLQ $<1$, it means agricultural sub sector is not expectable to be basic sector in the future.

Table 1.The Agricultural Sector Classification Based on the Composite LQ and DLQ

\begin{tabular}{ccc}
\hline Criteria & LQ $>1$ & LQ $<1$ \\
\hline DLQ $>1$ & Leading & Potential \\
DLQ $<1$ & Prospective & Disadvantaged \\
\hline
\end{tabular}

Source: Kuncoro, 2012

The explanation:

a. If DLQ>1 and LQ>1 (leading sector) implies that agricultural sub sectors have not been repositioning yet, it means the basic sector in the present will be basic sector in the future.

b. If $\mathrm{DLQ}<1$ and $\mathrm{LQ}>1$ (prospective sector) implies that agricultural sub sectors have been repositioning and it cannot be basic sector in the future.

c. If DLQ $>1$ and $\mathrm{LQ}<1$ (potential sector) implies that agricultural sub sectors have been repositioning from non basic sector to be basic sector in the future.

d. If $\mathrm{DLQ}<1$ and $\mathrm{LQ}<$ (disadvantaged sector) implies that agricultural sub sectors are not repositioning and it is still being non basic sector.

\section{RESULTS AND DISCUSSION}

\section{Trend of Agricultural GDP and Agricultural Contribution in Indonesia}

Agricultural sector has important role in Indonesia. The role of its such as produce of foods, contributor on GDP, contributor on foreign exchange, the largest absorption of labor, and multiplier effect. For that, Indonesian government is trying to develop agricultural sector. Performance of agricultural development can be seen from trend of agricultural GDP.

Agricultural GDP of Indonesia always increases from time to time except in 1998 which decrease from previous year that is caused by economic crisis. Agricultural GDP of Indonesia reached 327,549.7 billion rupiah in 2012. Figure 1 shows that agricultural GDP of Indonesia has increasing trend. The curve moves from lower left to upper right. 


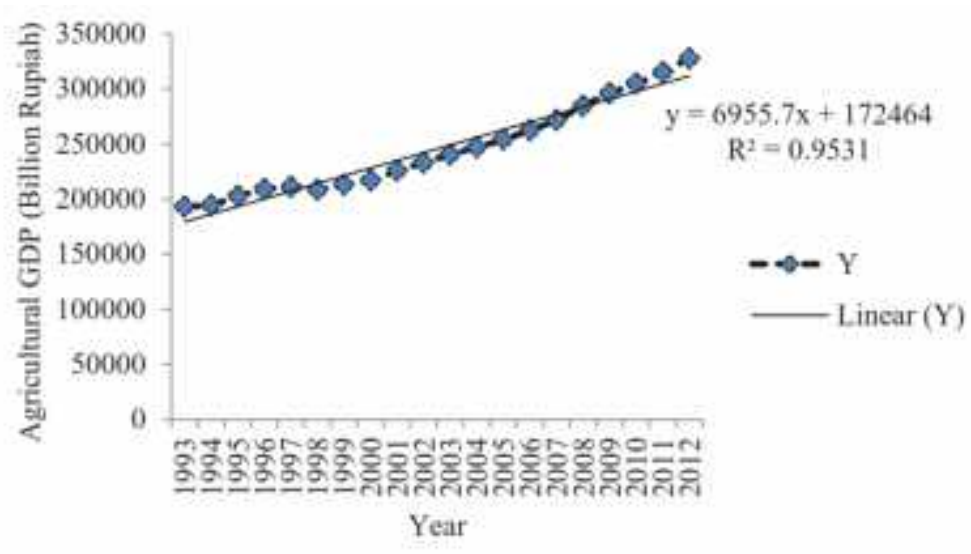

Figure 1.Trend of agricultural GDP

Source: BPS, several years of publication (processed)

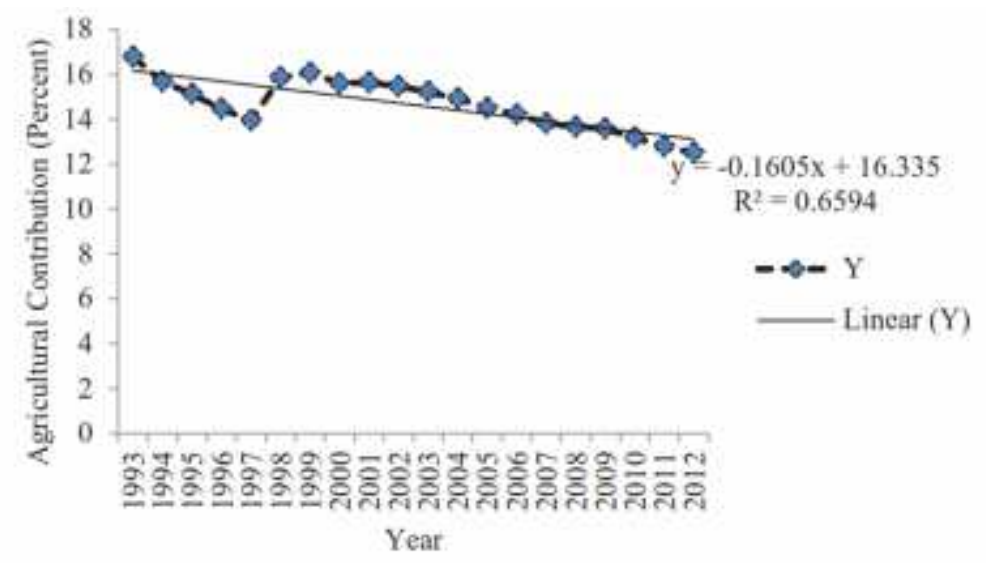

Figure 2.Trend of agricultural contribution on GDP Source: BPS, several years of publication (processed)

Agricultural GDP of Indonesia is formed by five agricultural sub sectors. Farm food crops is the largest contributor on agricultural GDP of Indonesia with average is $50.61 \%$ during 19932012. Farm non food crops contribute $15.40 \%$ on agricultural GDP of Indonesia then there are fishery, livestock, and forestry.

Agricultural contribution on GDP of Indonesia has tendency decrease during 19932012. Since 1993 until 1997, agricultural contribution on GDP of Indonesia is decline from year to year. But, economic crisis that is started in 1997 made agricultural contribution increased. Figure 2 shows the decreasing trend of agricultural contribution on GDP of Indonesia. The curve moves from upper right to lower left. Trend of agricultural GDP which increase and trend agricultural contribution which decrease show that economic development in Indonesia is going well. Kuznets cit Sukirno (2011) said that economic development will change the economic structure in a country. The change of economic structure is showed by decreasing of agricultural contribution on economy.

\section{The Role of Agricultural Sector and Sub Sectors in Indonesia a. Sumatera}

Base on table 1, it is known that agricultural sector is basic sector in 9 provinces of Sumatera cluster. Only in Kepulauan Riau Province, agricultural sector is not basic sector. It is because economy of Kepulauan Riau is dominated by industrial, trade, hotel and restaurant sector. Kepulauan Riau has Batam city as central business and manufacturing industry. Although agricultural sector is not basic sector in Kepulauan Riau, there is agricultural sub sector which is basic sub sector in Kepulauan Riau. Those are livestock and fishery sub sector. Fishery sub sector has high LQ value that is 5 . 
Table 1.The Average of LQ Value of Agricultural Sector and Sub Sectors by Province in Sumatera

\begin{tabular}{lcccccc}
\hline \multirow{2}{*}{ Province } & \multicolumn{5}{c}{ Agricultural Sub Sectors } & Agricultural \\
\cline { 2 - 6 } & 1 & 2 & 3 & 4 & 5 & Sector \\
\hline Aceh & 0.856 & 1.057 & 1.313 & 1.439 & 1.020 & 1.30 \\
Sumut & 0.708 & 2.489 & 0.881 & 0.825 & 0.671 & 1.69 \\
Sumbar & 1.072 & 0.215 & 0.743 & 1.027 & 0.777 & 1.62 \\
Riau & 0.2878 & 2.246 & 0.428 & 5.034 & 0.672 & 1.06 \\
Kepri & 0.113 & 0.338 & 1.257 & 0.209 & 4.508 & 0.33 \\
Jambi & 0.788 & 2.390 & 0.663 & 1.860 & 0.310 & 2.08 \\
Sumsel & 0.471 & 2.848 & 0.619 & 1.353 & 1.084 & 1.32 \\
Babel & 0.234 & 3.255 & 0.271 & 0.402 & 2.026 & 1.60 \\
Bengkulu & 0.924 & 1.967 & 0.626 & 0.678 & 0.667 & 2.66 \\
Lampung & 0.953 & 1.580 & 1.008 & 0.126 & 1.005 & 2.84 \\
\hline
\end{tabular}

Source: Data processed, 2014

Notes:
1 : Farm Food Crops
3 : Livestock
5 : Fishery
2 : Farm Non Food Crops
4 : Forestry

Table 2. The Average of DLQ Value of Agricultural Sub Sectors by Province in Sumatera

\begin{tabular}{lccccc}
\hline \multirow{2}{*}{ Province } & \multicolumn{5}{c}{ Agricultural Sub Sector } \\
\cline { 2 - 6 } & Farm Food Crops & $\begin{array}{c}\text { Farm Non Food } \\
\text { Crops }\end{array}$ & Livestock & Forestry & Fishery \\
\hline Aceh & 0.991 & 1.021 & 1.014 & 0.978 & 0.991 \\
Sumut & 0.992 & 1.004 & 0.985 & 1.013 & 0.995 \\
Sumbar & 0.994 & 1.040 & 0.978 & 0.998 & 0.990 \\
Riau & 0.974 & 1.022 & 1.002 & 1.009 & 0.989 \\
Kepri & 1.021 & 0.981 & 0.998 & 1.005 & 0.976 \\
Jambi & 0.987 & 1.038 & 0.973 & 0.945 & 0.968 \\
Sumsel & 1.000 & 1.009 & 0.993 & 0.985 & 0.971 \\
Babel & 1.009 & 0.994 & 0.996 & 0.985 & 0.978 \\
Bengkulu & 1.000 & 1.015 & 0.983 & 0.986 & 0.992 \\
Lampung & 1.004 & 0.992 & 0.994 & 1.044 & 0.986 \\
\hline Source: Dan
\end{tabular}

Source: Data Processed, 2014

Base on DLQ value in table 2, it is known that fishery sub sector in all provinces in Sumatera cluster has DLQ value smaller than 1 . It means that the growth of fishery sub sector in provinces in Sumatera cluster is lower than the growth of fishery sub sector in national level. It also means that fishery sub sector in provinces in Sumatera cluster cannot be basic sub sector in the future if economic condition does not change.

Farm non food crops sub sector is leading sector in 7 provinces in Sumatera cluster. This is not surprising, given the focus of agricultural development in Sumatera cluster is farm non food crops especially palm oil plantations.Development of farm non food crops in Sumatera cluster is effort of government to accelerating economic growth in there. But, this can cause problems in the future if it is not accompanied by development of other sub sectors. The problems that have appeared at this time are the conversion of farm food crops land and forests to plantation especially palm oil plantation (Table 3 ).

Jawa cluster consist of 6 provinces those are DKI Jakarta, Jawa Barat, Banten, Jawa Tengah, DI Yogyakarta, and Jawa Timur. Economic development activity in Jawa cluster focus on industrial and service sectors especially in DKI Jakarta and Jawa Barat. Base on table 4, it is known that agricultural sector is not basic sector in 2 provinces in Jawa cluster. Those provinces are DKI Jakarta and Banten. It means that agricultural production cannot meet local demand in those provinces. But, DKI Jakarta has basic sub sector that is fishery sub sector which has LQ value 2.07. Fishery is basic sub sector only in DKI Jakarta, while farm non food crops are basic sub sector in Jawa timur. Agricultural sub sector is not basic sub sector in all provinces in Jawa cluster is forestry sub sector. 
Table 3.Classification of Agricultural Sub Sector Base on LQ and DLQ Value by Province in Sumatera

\begin{tabular}{cccccc}
\hline \multirow{2}{*}{ Province } & \multicolumn{4}{c}{ Agricultural Sub Sectors } \\
\cline { 2 - 6 } & Farm Food Crops & $\begin{array}{c}\text { Farm Non Food } \\
\text { Crops }\end{array}$ & Livestock & Forestry & Fishery \\
\hline Aceh & IV & I & I & II & II \\
Sumut & IV & I & IV & III & IV \\
Sumbar & II & I & IV & II & IV \\
Riau & IV & I & III & I & IV \\
Kepri & III & IV & II & III & II \\
Jambi & IV & I & IV & II & IV \\
Sumsel & III & I & IV & II & II \\
Babel & III & II & IV & IV & II \\
Bengkulu & III & I & IV & IV & IV \\
Lampung & III & II & II & III & II \\
\hline
\end{tabular}

Source: Data processed, 2014

Notes:

I = Leading Sub Sector III = Potential Sub Sector

II = Prospective Sub Sector IV = Disadvantage Sub Sector

\section{b. Jawa}

Table 4.The Average of LQ Value Agricultural Sector and Sub Sectors by Province in Java

\begin{tabular}{lcccccc}
\hline \multirow{2}{*}{ Province } & \multicolumn{5}{c}{ Agricultural Sub Sectors } & Agricultural \\
\cline { 2 - 6 } & 1 & 2 & 3 & 4 & 5 & Sector \\
\hline DKI Jakarta & 0.998 & 0.846 & 0.505 & 0.000 & 2.071 & 0.01 \\
Jawa Barat & 1.495 & 0.358 & 1.054 & 0.214 & 0.328 & 1.04 \\
Banten & 1.227 & 0.510 & 1.673 & 0.096 & 0.604 & 0.58 \\
Jawa Tengah & 1.434 & 0.680 & 0.865 & 0.262 & 0.401 & 1.43 \\
DI Yogyakarta & 1.506 & 0.172 & 1.409 & 0.660 & 0.128 & 1.30 \\
Jawa TImur & 1.128 & 1.082 & 1.267 & 0.250 & 0.586 & 1.21 \\
\hline
\end{tabular}

Source: Data processed, 2014

Notes:

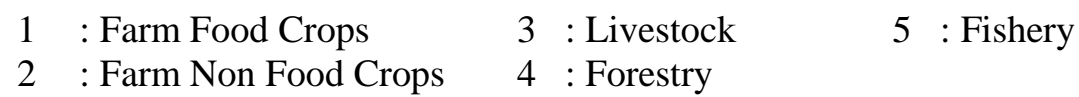

Table 5.The Average of DLQ Value of Agricultural Sub sectorsby Province in Jawa

\begin{tabular}{lccccc}
\hline \multirow{2}{*}{ Province } & \multicolumn{5}{c}{ Agricultural Sub Sectors } \\
\cline { 2 - 6 } & $\begin{array}{c}\text { Farm Food } \\
\text { Crops }\end{array}$ & $\begin{array}{c}\text { Farm Non Food } \\
\text { Crops }\end{array}$ & Livestock & Forestry & Fishery \\
\hline DKI Jakarta & 0.982 & 1.034 & 0.957 & 0.000 & 1.005 \\
Jawa Barat & 1.004 & 0.987 & 0.999 & 0.995 & 0.995 \\
Banten & 0.991 & 1.005 & 1.020 & 1.025 & 1.006 \\
Jawa Tengah & 1.002 & 0.969 & 1.029 & 1.003 & 0.988 \\
DI Yogyakarta & 1.001 & 0.978 & 0.971 & 1.314 & 1.036 \\
Jawa TImur & 1.003 & 0.979 & 1.003 & 1.007 & 0.946 \\
\hline Sowren
\end{tabular}

Source: Data processed, 2014

Farm food crops have DLQ value more than 1 in 4 provinces in Jawa cluster. Those provinces are Jawa Barat, Jawa Tengah, DI Yogyakarta, and Jawa Timur. DLQ value of farm food crop in DKI Jakarta and Banten are smaller than 1. It means that farm food crops in DKI Jakarta and Banten cannot be basic sub sector in the future. Farm non food crops have DLQ value more than 1 in DKI Jakarta and Banten (Table 5).

Base on table 6, it is known that farm food crops is leading sub sector in Jawa Barat, Jawa Tengah, DI Yogyakarta, and Jawa Timur. It means that farm food crops is basic sub sector now and can be basic sub sector in the future. 
Farm non food crops are potential sub sector in DKI Jakarta and Banten. Livestock is leading sub sector in Banten and Jawa Timur. Fishery is leading sub sector in DKI Jakarta.

Table 6. Classification of Agricultural Sub sectors Base on LQ and DLQ Value by Province in Jawa

\begin{tabular}{|c|c|c|c|c|c|}
\hline \multirow[b]{2}{*}{ Province } & \multicolumn{5}{|c|}{ Agricultural Sub Sectors } \\
\hline & $\begin{array}{c}\text { Farm Food } \\
\text { Crops }\end{array}$ & $\begin{array}{c}\text { Farm Non Food } \\
\text { Crops }\end{array}$ & Livestock & Forestry & Fishery \\
\hline DKI Jakarta & IV & III & IV & III & I \\
\hline Jawa Barat & I & IV & II & IV & IV \\
\hline Banten & II & III & I & III & III \\
\hline Jawa Tengah & I & IV & III & III & IV \\
\hline DI Yogyakarta & I & IV & II & III & III \\
\hline Jawa TImur & I & II & I & III & IV \\
\hline
\end{tabular}

Source: Data processed, 2014

Notes:

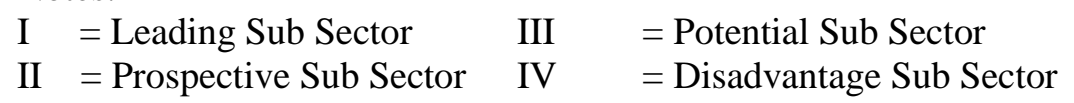

\section{c. Bali and Nusa Tenggara}

Economic development in Bali and Nusa Tenggara cluster was going well. It can be seen from trend agricultural GRDP which has increasing trend and trend of agricultural contribution which has decreasing trend in all of the provinces in Bali and Nusa Tenggara cluster. Base on table 7, Agricultural sector is basic sector in all of Bali and Nusa Tenggara cluster. Farm food crops are basic sub sector in Nusa Tenggara Barat and Nusa Tenggara Timur. Sub sectors which are become focus on MP3EI that is livestock is basic in Bali, Nusa Tenggara Barat, and Nusa Tenggara Timur. Fishery is basic sub sector in Bali.

Table 7. The Average of LQ Value of Agricultural Sector and Sub Sectors by Province in Bali and Nusa Tenggara

\begin{tabular}{lcccccc}
\hline \multirow{2}{*}{ Province } & \multicolumn{5}{c}{ Agricultural Sub Sectors } & Agricultural \\
\cline { 2 - 6 } & 1 & 2 & 3 & 4 & 5 & Sector \\
\hline Bali & 0.988 & 0.309 & 2.025 & 0.004 & 1.246 & 1.49 \\
NTB & 1.207 & 0.752 & 1.135 & 0.125 & 0.861 & 2.06 \\
NTT & 1.020 & 0.671 & 2.331 & 0.103 & 0.637 & 2.92 \\
\hline
\end{tabular}

Source: Data processed, 2014

Notes:

$\begin{array}{llll}1 & \text { : Farm Food Crops } & 3 & \text { : Livestock } \\ 2 & \text { : Farm Non Food Crops } & 4 & \text { : Forestry }\end{array}$

Base on table 7, it is known that farm non food crops and forestry are not basic sector in all provinces of Bali and Nusa Tenggara cluster. But farm food crops can be basic sector in the future in Nusa Tenggara Barat while forestry can be basic sector in the future in Bali and Nusa Tenggara Timur. Those are base on DLQ value on table 8 .

Base on table 8 , it is known that fishery sub sector has DLQ value smaller than 1 in all provinces of Bali and Nusa Tenggara cluster. It means that the growth of fishery sub sector is lower in provinces of Bali and Nusa Tenggara cluster is lower than the growth of its in national level. It also means that if economic
5 : Fishery

condition is same with this time, fishery can be basic sector in the future.

Farm food crops sub sector is leading sector in Nusa Tenggara Barat and Nusa Tenggara Timur. Livestock is leading sub sector in Bali and Nusa Tenggara Timur. The potential sub sector in Bali is fishery while in Nusa Tenggara Barat is livestock (Table 9).

\section{d. Kalimantan}

Kalimantan cluster consist of all provinces in Kalimantan Island those are Kalimantan Barat, Kalimantan Tengah, Kalimantan Selatan, and Kalimantan Timur. Economic development in Kalimantan cluster make contribution of agricultural sector on GRDP of provinces in Kalimantan decrease except in Kalimantan 
Selatan which fluctuated. Decreasing of agricultural contribution is cause by exploration of mining resource in Kalimantan.

Base on LQ value on table 10, agricultural sector is basic sector in 3 provinces in Kalimantan cluster. Those are Kalimantan Barat, Kalimantan Tengah, and Kalimantan Selatan. Farm non food crops is basic sub sector in Kalimantan Barat,
Kalimantan Tengah, and Kalimantan Selatan with superior commodity is palm oil. Base on BPS (2008), $80 \%$ of farm food crops GRDP of Kalimantan contribute from palm oil while 53\% of plantation land area in Kalimantan is also palm oil. Forestry sub sector is basic sub sector in all provinces of Kalimantan cluster.

Table 8.The Average of DLQ Value of Agricultural Sub Sectors by Province in Bali and Nusa Tenggara

\begin{tabular}{lccccc}
\hline & \multicolumn{5}{c}{ Agricultural Sub Sectors } \\
\cline { 2 - 6 } & $\begin{array}{c}\text { Farm Food } \\
\text { Crops }\end{array}$ & $\begin{array}{c}\text { Farm Non Food } \\
\text { Crops }\end{array}$ & Livestock & Forestry & \multirow{2}{*}{ Fishery } \\
\hline Bali & 0.999 & 0.991 & 1.001 & 1.121 & 0.993 \\
NTB & 1.002 & 1.002 & 0.999 & 0.956 & 0.989 \\
NTT & 1.010 & 0.972 & 1.011 & 1.021 & 0.997 \\
\hline
\end{tabular}

Source: Data processed, 2014

Table 9.Classification of Agricultural Sub Sectors Base on LQ and DLQ Value by Province in Bali and Nusa Tenggara

\begin{tabular}{|c|c|c|c|c|c|}
\hline \multirow[b]{2}{*}{ Province } & \multicolumn{5}{|c|}{ Agricultural Sub Sectors } \\
\hline & $\begin{array}{c}\text { Farm Food } \\
\text { Crops }\end{array}$ & $\begin{array}{c}\text { Farm Non Food } \\
\text { Crops }\end{array}$ & Livestock & Forestry & Fishery \\
\hline Bali & IV & IV & I & III & II \\
\hline NTB & I & III & II & IV & IV \\
\hline NTT & I & IV & I & III & IV \\
\hline
\end{tabular}

Source: Data processed, 2014

Notes:
I = Leading Sub Sector
III = Potential Sub Sector
II = Prospective Sub Sector
IV = Disadvantage Sub Sector

Table 10. The Average of LQ Value of Agricultural Sector and Sub Sectors by Province in Kalimantan

\begin{tabular}{lcccccc}
\hline \multirow{2}{*}{ Province } & \multicolumn{5}{c}{ Agricultural Sub Sectors } & Agricultural \\
\cline { 2 - 6 } & 1 & 2 & 3 & 4 & 5 & Sector \\
\hline Kalbar & 0.759 & 1.988 & 0.864 & 1.366 & 0.538 & 1.76 \\
Kalteng & 0.356 & 2.023 & 0.695 & 3.194 & 1.124 & 2.45 \\
Kalsel & 0.945 & 1.353 & 0.463 & 1.004 & 1.368 & 1.63 \\
Kaltim & 0.322 & 0.710 & 0.798 & 6.232 & 1.279 & 0.48 \\
\hline
\end{tabular}

Source: Data processed, 2014

Notes:

$\begin{array}{llllll}1 & \text { : Farm Food crops } & 3 & \text { : Livestock } & 5 & \text { : Fishery } \\ 2 & \text { : Farm Non Food crops } & 4 & \text { : Forestry } & & \end{array}$

Table 11.The Average of DLQ Value of Agricultural Sub Sectors by Province in Kalimantan

\begin{tabular}{lccccc}
\hline \multirow{2}{*}{ Province } & \multicolumn{5}{c}{ Agricultural Sub Sectors } \\
\cline { 2 - 6 } & $\begin{array}{c}\text { Farm Food } \\
\text { Crops }\end{array}$ & $\begin{array}{c}\text { Farm Non Food } \\
\text { Crops }\end{array}$ & Livestock & Forestry & Fishery \\
\hline Kalbar & 0.997 & 1.030 & 0.986 & 0.965 & 0.988 \\
Kalteng & 0.992 & 1.075 & 1.031 & 0.919 & 0.974 \\
Kalsel & 0.997 & 1.036 & 1.012 & 0.959 & 0.972 \\
Kaltim & 1.025 & 1.090 & 1.039 & 0.960 & 1.035 \\
\hline
\end{tabular}

Source: Data processed, 2014 
Base on table 11, it is known that DLQ value of farm non food crops is more than one in all provinces of Kalimantan cluster. It means that the growth of farm non food crops in provinces of Kalimantan cluster is faster than its growth in national level. DLQ value of forestry sub sector show that the growth of it in provinces of Kalimantan is lower than in national level. In Kalimantan Timur there are sub sectors which have DLQ value more than 1, those are farm food crops and fishery sub sector.

Table 12. Classification of Agricultural Sub Sectors Base on LQ and DLQ Value by Province in Kalimantan

\begin{tabular}{|c|c|c|c|c|c|}
\hline \multirow[b]{2}{*}{ Province } & \multicolumn{5}{|c|}{ Agricultural Sub Sectors } \\
\hline & $\begin{array}{c}\text { Farm Food } \\
\text { Crops }\end{array}$ & $\begin{array}{c}\text { Farm Non Food } \\
\text { Crops }\end{array}$ & Livestock & Forestry & Fishery \\
\hline Kalbar & IV & I & IV & II & IV \\
\hline Kalteng & IV & I & II & II & II \\
\hline Kalsel & IV & I & III & II & II \\
\hline Kaltim & III & III & III & II & I \\
\hline
\end{tabular}

Source: Data processed, 2014

Notes:

$\begin{array}{llll}\text { I } & =\text { Leading Sub Sector } & \text { III } & =\text { Potential Sub Sector } \\ \text { II } & =\text { Prospective Sub Sector } & \text { IV } & =\text { Disadvantage Sub Sector }\end{array}$

Classification of agricultural sub sector on table 12 show that farm food crops is leading sub sector in Kalimantan Barat, Kalimantan Tengah, and Kalimantan Selatan. In Kalimantan cluster, forestry sub sector is repositioning as non basic sub sector in the future (classification II).

\section{e. Sulawesi}

Base on table 13, Agricultural sector is basic sector in all provinces of Sulawesi cluster where farm food crops as be basic sub sector. Farm food crop is not being basic sub sector in Sulawesi cluster. Farm non food crop is basic sub sector in all provinces of Sulawesi cluster.

Table 13. The Average of LQ Value of Agricultural Sector and Sub Sectors by Province in Sulawesi

\begin{tabular}{lcccccc}
\hline \multirow{2}{*}{\multicolumn{1}{c}{ Province }} & \multicolumn{5}{c}{ Agricultural Sub Sectors } & Agricultural \\
\cline { 2 - 6 } & 1 & 2 & 3 & 4 & 5 & Sector \\
\hline Sulut & 0.656 & 2.161 & 0.789 & 0.836 & 1.296 & 1.42 \\
Gorontalo & 0.911 & 1.359 & 1.160 & 0.674 & 0.873 & 2.12 \\
Sulteng & 0.717 & 1.979 & 0.618 & 1.616 & 1.145 & 2.82 \\
Sulsel & 0.971 & 1.499 & 0.353 & 0.075 & 1.524 & 2.34 \\
Sulbar & 0.732 & 2.878 & 0.374 & 0.258 & 0.758 & 3.63 \\
Sul Tenggara & 0.436 & 2.048 & 1.197 & 0.586 & 1.835 & 2.49 \\
\hline
\end{tabular}

Source: Data processed, 2014

Notes:

$$
\begin{array}{llll}
1 & \text { : Farm Food Crops } & 3 & \text { : Livestock } \\
2 & \text { : Farm Non Food Crops } & 4 & \text { : Forestry }
\end{array}
$$

Base on table 14, it is known that DLQ value of farm food crops is more than one in Gorontalo and Sulawesi Selatan. It means that the growth of farm food crops in there is faster than its growth in national level. Although, farm non food crops is basic sub sector in all provinces of Sulawesi cluster but just in 3 provinces farm non food crops has DLQ value more than 1 . Those provinces are Sulawesi Utara, Sulawesi Tengah, and Sulawesi Selatan.

Classification of agricultural sub sector base on LQ and DLQ value can be seen on table 15 . Farm food crops sub sector is not leading sub

\section{5 : Fishery}

sector in all provinces of Sulawesi cluster but it potential sub sector in Gorontalo and Sulawesi Selatan. It means that farm food crops in Gorontalo and Sulawesi Selatan still can be basic sub sector in the future. Farm non food crops sub sector is leading sector in Sulawesi Utara, Sulawesi Tengah, and Sulawesi Selatan. Livestock is leading sub sector in Gorontaro and Sulawesi Tenggara but it is disadvantage sub sector in Sulawesi Tengah, Sulawesi Selatan, and Sulawesi Barat. Forestry is leading sub sector in Sulawesi Tengah and it is potential sub sector in 
Sulawesi Barat and Sulawesi Tenggara. Fishery is leading sub sector in Sulawesi Utara.

\section{f. Maluku and Papua}

Papua and Maluku cluster consist of 4 provinces; those are Maluku, Maluku Utara, Papua, and Papua Barat. Agricultural GRDP has increasing trend in Maluku Utara, Papua, and Papua Barat while agricultural contribution has decreasing trend only in Papua. It means that economic development in Papua is better than 3 others provinces. Base on table 16, agricultural sector is basic sector in all provinces of Papua and Maluku cluster. From 5 agricultural sub sectors, there are 3 sub sectors which is basic sub sector. Farm non food crop is basic sub sector in Maluku, while forestry and fishery are basic sub sectors in Maluku, Papua, and Papua Barat.

Table 14. The Average of DLQ Value of Agricultural Sub Sectors by Province in Sulawesi

\begin{tabular}{lccccc}
\hline \multirow{2}{*}{ Province } & \multicolumn{3}{c}{ Agricultural Sub Sectors } \\
\cline { 2 - 6 } & $\begin{array}{c}\text { Farm Food } \\
\text { Crops }\end{array}$ & $\begin{array}{c}\text { Farm Non Food } \\
\text { Crops }\end{array}$ & Livestock & Forestry & Fishery \\
\hline Sulut & 0.992 & 1.002 & 1.002 & 0.904 & 1.009 \\
Gorontalo & 1.018 & 0.964 & 1.010 & 0.964 & 0.992 \\
Sulteng & 0.982 & 1.044 & 0.961 & 1.000 & 0.968 \\
Sulsel & 1.000 & 1.004 & 0.989 & 1.015 & 0.994 \\
Sulbar & 0.999 & 0.989 & 0.994 & 0.982 & 1.025 \\
Sul Tenggara & 0.996 & 0.985 & 1.007 & 1.007 & 0.997 \\
\hline
\end{tabular}

Source: Data processed, 2014

Table 15. Classification of Agricultural Sub Sectors Base on LQ and DLQ by Province in Sulawesi

\begin{tabular}{|c|c|c|c|c|c|}
\hline \multirow[b]{2}{*}{ Province } & \multicolumn{5}{|c|}{ Agricultural Sub Sectors } \\
\hline & $\begin{array}{l}\text { Farm Food } \\
\text { Crops }\end{array}$ & $\begin{array}{c}\text { Farm Non Food } \\
\text { Crops }\end{array}$ & Livestock & Forestry & Fishery \\
\hline Sulut & IV & I & III & IV & I \\
\hline Gorontalo & III & II & I & IV & IV \\
\hline Sulteng & IV & I & IV & I & II \\
\hline Sulsel & III & I & IV & III & II \\
\hline Sulbar & IV & II & IV & IV & III \\
\hline Sul Tenggara & IV & II & I & III & II \\
\hline
\end{tabular}

Source: Data processed, 2014

Notes:

$\begin{array}{llll}\text { I } & =\text { Leading Sub Sector } & \text { III } & =\text { Potential Sub Sector } \\ \text { II } & =\text { Prospective Sub Sector } & \text { IV } & =\text { Disadvantage Sub Sector }\end{array}$

Table 16. The Average of LQ Value Agricultural Sector and Sub Sectors by Province in Maluku and Papua

\begin{tabular}{lcccccc}
\hline \multirow{2}{*}{ Province } & \multicolumn{5}{c}{ Agricultural Sub Sectors } & Agricultural \\
\cline { 2 - 6 } & 1 & 2 & 3 & 4 & 5 & Sector \\
\hline Maluku & 0.480 & 1.453 & 0.274 & 1.622 & 2.709 & 2.21 \\
Maluku Utara & 0.531 & 3.211 & 0.311 & 0.964 & 0.852 & 2.58 \\
Papua & 0.956 & 0.239 & 0.558 & 2.769 & 1.466 & 1.05 \\
Papua Barat & 0.351 & 0.631 & 0.451 & 4.734 & 2.376 & 1.86 \\
\hline
\end{tabular}

Source: Data processed, 2014

Notes:

$\begin{array}{llll}1 & : \text { Farm Food Crops } & 3 & : \text { Livestock } \\ 2 & \text { :Farm Non Food Crops } & 4 & \text { : Forestry }\end{array}$

DLQ value of farm food crops in all provinces of Papua and Maluku cluster is bigger than 1, it means that the growth of farm food crops is faster than its growth in national level. Farm non food crops have DLQ value more than 1 in Maluku
Utara, Papua, and Papua Barat while livestock has DLQ value more than 1 in Maluku and Papua Barat. DLQ value of forestry is more than 1 in Maluku Utara while fishery in Maluku and Papua (Table 17). 
Table 17. The Average of DLQ Value Agricultural Sub Sectors by Province in Maluku and Papua

\begin{tabular}{lccccc}
\hline \multirow{2}{*}{ Province } & \multicolumn{5}{c}{ Agricultural Sub Sectors } \\
\cline { 2 - 6 } & $\begin{array}{c}\text { Farm Food } \\
\text { Crops }\end{array}$ & $\begin{array}{c}\text { Farm Non Food } \\
\text { Crops }\end{array}$ & Livestock & Forestry & Fishery \\
\hline Maluku & 1.008 & 0.984 & 1.010 & 0.901 & 1.029 \\
Maluku Utara & 1.003 & 1.001 & 0.981 & 0.1004 & 0.970 \\
Papua & 1.005 & 1.063 & 0.989 & 0.979 & 1.015 \\
Papua Barat & 1.017 & 1.018 & 1.030 & 0.995 & 0.982 \\
\hline
\end{tabular}

Source: Data processed, 2014

Table 18. Classification of Agricultural Sub Sectors Base on LQ and DLQ Value by Province in Maluku and Papua

\begin{tabular}{|c|c|c|c|c|c|}
\hline \multirow[b]{2}{*}{ Province } & \multicolumn{5}{|c|}{ Agricultural Sub Sectors } \\
\hline & $\begin{array}{l}\text { Farm Food } \\
\text { Crops }\end{array}$ & $\begin{array}{c}\text { Farm Non Food } \\
\text { Crops }\end{array}$ & Livestock & Forestry & Fishery \\
\hline Maluku & III & II & III & II & I \\
\hline Maluku Utara & III & I & IV & III & IV \\
\hline Papua & III & III & IV & II & I \\
\hline Papua Barat & III & III & III & II & II \\
\hline
\end{tabular}

Source: Data processed, 2014

Notes:
I = Leading Sub Sector
II = Prospective Sub Sector
III = Potential Sub Sector
IV = Disadvantage Sub Sector

Base on classification of agricultural sub sector on table 18 , it is known that farm food crops is leading sub sector in Maluku Utara while fishery is leading sub sector in Maluku and Papua. Leading sub sector means that the sub sector is basic sub sector this time and can be basic sub sector in the future. Farm food crops are potential sub sector which can develop in all provinces of Papua and Maluku cluster.

\section{CONCLUSION}

1. Agricultural GDP in Indonesia has increasing trend while agricultural contribution in Indonesia has decreasing trend. It is showed that economic development in Indonesia is going well.

2. Agricultural sector is basic sector in 29 provinces. Those are Aceh, Sumatera Utara, Sumatera Barat, Riau, Jambi, Sumatera Selatan, Kep. Bangka Belitung, Bengkulu, Lampung, Jawa Barat, Jawa Tengah, DI Yogyakarta, Jawa Timur, Bali, Kalimantan Barat, Kalimantan Tengah, Kalimantan
Selatan, Sulawesi Utara, Gorontalo, Sulawesi Tengah, Selawesi Barat, Sulawesi Selatan, Sulawesi Tenggara, Nusa Tenggara Barat, Nusa Tenggara Timur, Maluku, Maluku Utara, Papua, and Papua Barat. Farm food crop is leading sub sector in 6 provinces, farm non food crops is leading sub sector in 14 provinces, livestock is leading sub sector in 3 provinces, forestry is leading sub sector in 1 provinces, fishery is leading sub sector in 5 provinces.

\section{REFERENCES}

Anonim. 2006. Rencana Strategis Kementerian Pertanian 2005-2009. Kementerian Pertanian. www.pertanian.go.id accessed: 3/12/2013

Kuncoro, Mudrajad. 2012. Perencanaan Daerah. Salemba Empat. Jakarta

Sukirno, Sadono. 2011. Ekonomi Pembangunan cetakan ke-4. Kencana Prenada Media Grop. Jakarta

Tarigan, Robinson. 2009. Ekonomi Regional Teori dan Aplikasi. Bumi Aksara. Jakarta 